\title{
Business models for residential retrofit in the UK: a critical assessment of five key archetypes
}

\author{
Donal Brown (iD
}

Received: 6 June 2017 / Accepted: 30 January 2018 / Published online: 14 March 2018

(C) The Author(s) 2018

\begin{abstract}
The comprehensive retrofit of residential buildings has significant potential to reduce carbon emissions and provide additional heath and economic benefits. However, in countries such as the UK, much of this potential is yet to be realised. This paper shows how the concept of 'business models' (BMs) can be a powerful tool for understanding the challenge of improving energy performance and reducing carbon emissions in residential buildings. Through a review of contemporary literature and 18 semi-structured interviews, the paper describes and compares five distinct BM archetypes: the atomised market model, market intermediation model, one-stop-shop, energy services agreement and managed energy services agreement. These models range from the traditional approach to highly innovative energy service contracts. The paper further illustrates how the UK and EU market for retrofitting residential buildings is beginning to trial the more innovative BMs. These emerging BMs are characterised by increasingly industrialised processes and integrated supply chains, a holistic customer offering and single point of sale, longterm energy-saving performance contracts (ESPC) and integral project finance. It is argued that whilst the traditional $\mathrm{BM}$ is suitable for the implementation of single or piecemeal energy-saving measures, BM innovation will be required to meet the UK's ambitious climate change targets.
\end{abstract}

D. Brown $(\square)$

Centre on Innovation and Energy Demand, SPRU, Jubilee

Building, University of Sussex, Brighton, Sussex, UK

e-mail: Donal.Brown@sussex.ac.uk
Keywords Energy efficiency · Retrofit · Housing · Business models $\cdot$ ESCO $\cdot$ ESPC $\cdot$ Value proposition . Supply chain - Customer interface $\cdot$ Financial model . Governance

\section{Introduction}

The United Kingdom (UK) has an ambitious target to reduce greenhouse gas (GHG) emissions by $80 \%$ by 2050, relative to 1990 levels (Treasury, 2008). To this end, the UK government has set legally binding, 5-year carbon budgets that include targets for reducing emissions in all sectors of the UK economy (CCC 2013). In 2016, buildings were responsible for over a third of the UK's GHG emissions, with $22 \%$ from the residential sector alone (CCC 2016). Improving the energy efficiency of residential buildings can also improve occupant's health (Willand et al. 2015) and reduce fuel poverty (Sovacool 2015). In the UK, the energy performance of residential buildings is measured using the 'Standard Assessment Procedure' (SAP), ${ }^{1}$ where a SAP score of 100 equates to an exemplary dwelling. In 2012, the average SAP for UK homes was 59, compared to only 45 in 1996 (DECC 2015).

Progress in improving the energy performance of residential buildings has stalled since 2012 (CCC 2016). The UK still has one of the oldest and least energy efficient

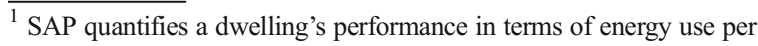
unit floor area, a fuel-cost-based energy efficiency rating (the SAP Rating) and emissions of $\mathrm{CO} 2$ (the Environmental Impact Rating) (GOV.UK 2017).
} 
housing stocks in Europe, and two thirds of the existing buildings are likely to exist in 2050 (Fylan et al. 2016). Older, solid walled properties constitute around $27 \%$ of the UK stock and have a large energy-saving potential (Element Energy 2013), yet only around 4\% have had solid wall insulation (SWI) installed (CCC 2016). The UK also has a high proportion (67\%) of owner-occupied housing, with $19 \%$ in social housing and $14 \%$ in private rented sectors (CCC 2016). The Committee on Climate Change (CCC 2015) estimates that there is cost effective ${ }^{2}$ potential to reduce direct emissions ${ }^{3}$ from all buildings by $32 \%$ to 2030 , with further savings available from the implementation of onsite microgeneration, with the need to achieve near-zero emissions from the sector by 2050 (CCC 2016). A 2013 policy initiative to improve energy efficiency in this sector (the 'Green Deal') proved to be a high-profile failure, achieving only 15,000 installations (mostly new boilers) rather than the two million a year that were envisaged (Rosenow and Eyre 2016). Since the remaining policies for energy efficiency in housing are relatively limited in ambition and scope, the carbon targets for this sector may not be achieved (Guertler and Rosenow 2016).

Emissions from UK residential buildings largely derive from gas use for space and water heating, and electricity use for lighting and appliances. Alongside efficient appliances and behaviour changes, the majority of these emissions can be reduced by the retrofit of three types of measure (Mallaburn and Eyre 2014): improving the building fabric of properties, adopting low-carbon heat technologies such as heat pumps and building-integrated electricity microgeneration, such as solar PV (CCC 2013). The CCC projections for 2030 include 2 million SWI and 2.5 million heat pump installations. This represents a sevenfold increase in properties with SWI and a massive upscaling in low-carbon heat (CCC 2016).

The improper installation of deeper single measures such as SWI has, however, the potential to cause damaging unintended consequences ${ }^{4}$ (Davies and Oreszczyn 2012).

\footnotetext{
2 The CCC defines the cost-effective path as comprising measures that cost less than the projected carbon price across their lifetimes together with measures that may cost more than the projected carbon price, but are necessary in order to manage costs and risks of meeting the 2050 target (CCC 2013).

${ }^{3}$ Those that result from heating, ventilation and cooling systems as well as and hot water. This term excludes emissions from electricity consumption.

${ }^{4}$ Such as mould growth, poor air quality and interstitial condensation, due to poor detailing, and in-sufficient consideration of building physics, airtightness and ventilation (Milsom 2016)
}

A comprehensive residential retrofit, where the entire building is treated as a system rather than as individual elements or measures, is likely to mitigate such issues and achieve greater reductions in emissions (Hansford 2015). Such an approach typically involves multiple measures and strategies for insulation, draught proofing, ventilation and heating systems, and may also include microgeneration (Milsom 2016). Consequently, if the $\mathrm{UK}$ is to meet its ambitious climate change targets, comprehensive residential retrofit, involving multiple coordinated measures will need to become the norm (Lewis and Smith 2013).

This paper argues that despite significant policy action in this area, a major reason for the slow progress is the limitations of the traditional business model (BM) through which energy efficiency measures are delivered. This model is characterised by a piecemeal offering, with a fragmented supply chain, a focus on single (rather than multiple, complementary) measures, and no guarantees on performance. Yet, research that identifies how alternative BMs might be more effective in delivering comprehensive residential retrofit is largely absent from the literature.

This study addresses this gap. First, it uses the BM concept to better understand the challenge of residential retrofit; second, it identifies the range of BMs currently used for delivering residential retrofit in the UK and the EU; third, it evaluates how and why the characteristics of these BMs influence their potential in delivering comprehensive residential retrofits.

The study addresses the following research questions:

1. What insights does the BMs concept offer for the challenge of residential retrofit?

2. What BMs are currently used for residential retrofit and how do they differ?

3. How and why do the characteristics of these alternative BMs influence their potential for delivering comprehensive residential retrofit?

Through a review of the academic literature on both BMs and residential retrofit, together with semi-structured interviews with stakeholders from the residential retrofit industry, this paper explores how more innovative BMs could enable greater uptake of comprehensive residential retrofit. The paper is structured as follows: "Literature on business models, energy services and residential retrofit" section 
summarises the theoretical literature on BMs and the empirical literature on residential retrofit, and outlines the value of using the former to understand the latter. "Methods" section outlines the research methodology, whilst "Retrofit business models: five key archetypes" section describes five key BM archetypes for residential retrofit. "Summary of findings" section summarises the empirical results and highlights the implications for the successful delivery of comprehensive residential retrofit. "Discussion" section places these findings in the context of the wider literature on BMs and residential retrofit. "Conclusions" section concludes and provides some suggestions for further research.

\section{Literature on business models, energy services and residential retrofit}

\section{Literature on business models}

Throughout history, the development of new BMs has been instrumental to the diffusion of innovations such as commercial aviation, modern customer electronics and the Internet (Teece 2010). Meeting the sustainability challenges of the twenty-first century is likely to require a major transition in many sectors of the economy. This transition requires the development and rapid diffusion of multiple low-carbon innovations throughout the housing sector. Thus, innovations such as distributed energy $^{5}$ and comprehensive residential retrofit may require novel BMs before they are viable on a large scale, due to their incompatibility with existing industry practices (Hall and Roelich 2016; Winther and Gurigard 2017). Consequently, various scholars have identified how such systemic innovations may have specific characteristics that are more suitable to certain novel BMs (Hall and Roelich 2016; Richter 2012; Steinberger et al. 2009). In addition, new BMs for energy services may also enable a more comprehensive approach to improving the energy performance of buildings (Kangas et al. 2017).

The $\mathrm{BM}$ is therefore increasingly adopted as lens for evaluating firm strategies to address sustainability challenges (Boons et al. 2013). Yet, whilst a few key

\footnotetext{
${ }^{5}$ Defined as electricity generation feeding into the local distribution network (operating from $132 \mathrm{kV}$ down to $230 \mathrm{~V}$ ), as opposed to the regional or national transmission grid (which operates from $400 \mathrm{kV}$ and $275 \mathrm{kV})$.
}

studies provide points of reference for characterising $\mathrm{BMs}$, the term remains contested, both in terms of the organisational components that are described (Osterwalder et al. 2005) and the system boundaries of individual firms or networks of firms (DaSilva and Trkman 2014; Upward and Jones 2015; Zott et al. 2011). Perhaps the most commonly used definition is from Osterwalder and Pigneur (2010) who identify four basic components: the value proposition, the supply chain, the customer interface and the financial model (Boons and Lüdeke-Freund 2013). This characterisation provides a 'meta-model' of features that are generic to all BMs and can thus be applied in multiple contexts (Osterwalder et al. 2005). BMs therefore incorporate the nature of the value delivered to customers, the activities involved in delivering that value and the means of capturing revenue from these activities (Boons et al. 2013).

However, the study of the BM of individual firms overlooks the interdependent and networked nature of the delivery of good and services (Hellström et al. 2015; Zott and Amit 2010). BMs thus involve a range of activities that may span the boundaries of multiple organisations (Zott and Amit 2010). This highlights the need for what has been termed a systems perspective on BMs (Bolton and Hannon 2016). This perspective emphasises the governance of BMs, both in terms of the role of different actors and the chosen mode of governance, for example, from highly integrated to highly outsourced approaches (Amit and Zott 2001).

Business models, energy services and residential retrofit

Several studies use the BM concept to describe how organisations provide energy services (Duplessis et al. 2012; Hannon et al. 2015; Kindström and Ottosson 2016; Labanca et al. 2014; Okkonen and Suhonen 2010). Energy service BMs move beyond the prevailing value proposition based on the sale of energy commodities (gas, electricity, fuel oil), towards an alternative value proposition based on the energy service itself (warmth, light, hot water) (Steinberger et al. 2009). This creates incentives for suppliers to reduce energy demand in order to minimise the energy cost of supplying the service (Bertoldi et al. 2006; Sorrell 2007). Where these contracts include guaranteed reductions in energy consumption or costs for the client, they are termed Energy Savings Performance Contracts (ESPC), with the relevant supplier being termed an Energy Service Company 
(ESCO) (Kindström and Ottosson 2016). The market for ESPCs is largely confined to industry and nonresidential buildings (Hannon and Bolton 2015; Kindström and Ottosson 2016; Okkonen and Suhonen 2010), since the transaction costs in the residential market are relatively high (Sorrell 2007). However, BleylAndroschin and Schinnerl (2007) propose a number of models for ESPCs that could promote building envelope refurbishment. Indeed, several residential examples of ESPCs are now emerging across the EU (Irrek et al. 2013; Labanca et al. 2014).

Relatively few academic studies investigate BMs for residential retrofit. Recent UK case studies focus on new models for distributed energy (Foxon et al. 2015; Hall and Roelich 2016; Hannon and Bolton 2015), but do not assess the specific challenges posed by residential retrofit. Gauthier and Gilomen (2016) compare two French case studies of residential retrofit BMs, but focus on individual firms within the project, rather than the overall retrofit process. Mahapatra et al. (2013) evaluate the opportunities and barriers of one-stop-shop BMs in Scandinavia for residential retrofit, where multiple services and finance are provided by one organisation. Winther and Gurigard (2017) explore a failed attempt to implement ESPC contracts in a Norwegian case study, whilst Moschetti and Brattebø (2016) map out possible alternative BMs for residential buildings, yet provide limited empirical examples.

Cost effective energy efficiency measures face several barriers to their implementation (Sorrell et al. 2004). These barriers can be grouped into four categories: financial, social and behavioural, supplier competence and performance risk (Fylan et al. 2016). The five components of the BM outlined in "Literature on business models" section correspond to each of these interrelated barriers. Studies identify problems with a value proposition focused on estimated, rather than guaranteed energy performance (Pettifor et al. 2015), and final energy services, such as temperature and comfort (Roelich et al. 2015). Further barriers to uptake are identified as a customer interface that is ineffective in engaging consumers (Owen et al. 2014; Wilson et al. 2015), poorly developed supply chains and retrofit performance gaps (where modelled savings are not realised) (Gupta and Chandiwala 2010; Kelly et al. 2012; Snape et al. 2015) and a lack of appeal in the financial model (Marchand et al. 2015). Other studies have identified the importance of intermediary actors in the governance of retrofit (Bleyl et al. 2013; Kivimaa and Martiskainen 2017) and as a means of reducing transaction costs for ESCO BMs (Nolden et al. 2016). Thus, the five components of BMs provide a comprehensive framework for understanding the solutions to these barriers.

Business model framework for residential retrofit

The following section describes how a BM framework can improve understanding of the challenges in delivering residential retrofit. This framework combines the four components of BMs outlined by Boons and Lüdeke-Freund (2013) with the additional component of BM governance as described by Amit and Zott (2001) and Zott and Amit (2010). The components of a BM are therefore the value proposition, supply chain, customer interface, financial model and $\mathrm{BM}$ governance.

\section{Value proposition}

The value proposition refers to the value or utility from goods and services that an organisation provides to the customer (Boons and Lüdeke-Freund 2013; Engelken et al. 2016). New BMs do not necessarily provide a novel value proposition (Lopez et al. 2014), although a shift towards ESPCs may also create stronger incentives for energy efficiency improvements (Steinberger et al. 2009). Thus, the value proposition may constitute simply the implementation of energy-saving retrofit measures or a move towards some form of ESPC. Suppliers may also emphasise other sources of value for customers, such as improvements in aesthetics, comfort, health and well-being rather than energy cost savings alone (Knoeri et al. 2016). ESPCs may also enable more comprehensive residential retrofit projects (Kangas et al. 2017; Winther and Gurigard 2017).

\section{Supply chain}

The supply chain is the upstream relationships between an organisation and its suppliers (Boons and LüdekeFreund 2013). This comprises the logistical and technical elements that enable delivery of the value proposition (Osterwalder 2004). In the context of residential retrofit, the supply chain includes the design and delivery of the retrofit, encompassing both the installation and the operational phases, potentially across multiple suppliers and consultants. Both integration of the supply chain and improvements in project management 
may enable more comprehensive residential retrofits (Mahapatra et al. 2013) increased material efficiency and quality control (Lopez et al. 2014) and industrialisation/automation of manufacturing processes and logistics, such as the use of off-site manufacture techniques (Energiesprong 2014).

\section{Customer interface}

The customer interface covers all downstream, customer-related interactions (Boons and LüdekeFreund 2013). This includes the relationship the customer has with the supplier organisations in terms of marketing, sales and distribution channels and the ongoing relationship with the product or service (Osterwalder and Pigneur 2010). In a retrofit context, the customer may include homeowners, landlords or social housing providers. Where customers separately source retrofit measures, finance and energy audits, they may encounter multiple interfaces and points of sale.

\section{Financial model}

The financial model constitutes the combination of an organisation's capital and operational expenditures with its means of revenue generation from business activities (Osterwalder et al. 2005). Typically, the financial objective in energy retrofits is to recover the capital costs of the measures from the saving in energy bills or from the revenues from onsite electricity generation. A range of financing mechanisms have thus been developed to overcome the initial capital cost, where the objective is typically to ensure that repayments are equal to or lower than the energy cost savings. A suitable finance mechanism is often the catalyst for a viable retrofit project, with the associated cost of capital being critical to the economic viability of many measures (Gouldson et al. 2015).

\section{Business model governance}

BM governance involves both the control and management of the individual components (Zott and Amit 2010) and the organisational form of the BM (Amit and Zott 2001). As such, BMs may involve a constellation of firms that interact to provide a service or product (Boons and Lüdeke-Freund 2013), leading to interdependencies between various actors in the delivery of the value proposition (Zott and
Amit 2010). Consequently, the range of governance approaches lie along a continuum, with integrated, hierarchical firms at one end, and arm's-length, market-based contractual relationships at the other (Treib et al. 2007). Where a hierarchical approach is adopted, the BM components are internal to a single organisation, whereas in a market-based approach, multiple organisations are likely to be involved. More common is a hybrid of these, with most BMs employing varying degrees of market-based, hierarchical and trust-based governance; the latter involving recurrent relationships with trusted partners (Bradach and Eccles 1989; Eriksson 2008).

In residential retrofit, managers, intermediaries and government actors may each play important roles in governance (Bolton and Hannon 2016). Governance (or lack of) becomes a particularly important consideration in highly networked arrangements where intermediaries (Bleyl et al. 2013; Kivimaa and Martiskainen 2017), such as community (Seyfang et al. 2013), municipal actors (Webb et al. 2016) work alongside private firms. In particular, innovative BMs may require these system builders to foster trust and coordinate the actions of multiple stakeholders (Bolton and Hannon 2016).

\section{Methods}

This study began with a comprehensive review of the academic and grey literature on retrofit BMs. The literature review identified a number of texts and reports ${ }^{6}$ that described the range of approaches to retrofit that are currently employed in the UK and EU (De Groote et al. 2016; Edrich et al. 2010; EST 2011; Jankel 2013; Kats et al. 2011; Kim et al. 2012; Koh et al. 2013; Mahapatra et al. 2013; Milin and Bullier 2011; Straub 2016; Sweatman and Managan 2010; The Rockefeller Foundation and DB Climate Change Advisors 2012). Five key archetypes of retrofit BMs were subsequently identified, summarised in Table 1 and described in detail in "Retrofit business models: five key archetypes"

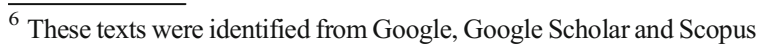
using several search terms. Search terms included retrofit BM, retrofit financial model, energy efficiency BM, retrofit intermediary, residential energy service contracts, community retrofit, cooperative retrofit, local authority retrofit, retrofit one-stop-shop, energy services agreement, residential energy performance contract and managed energy service agreement
} 


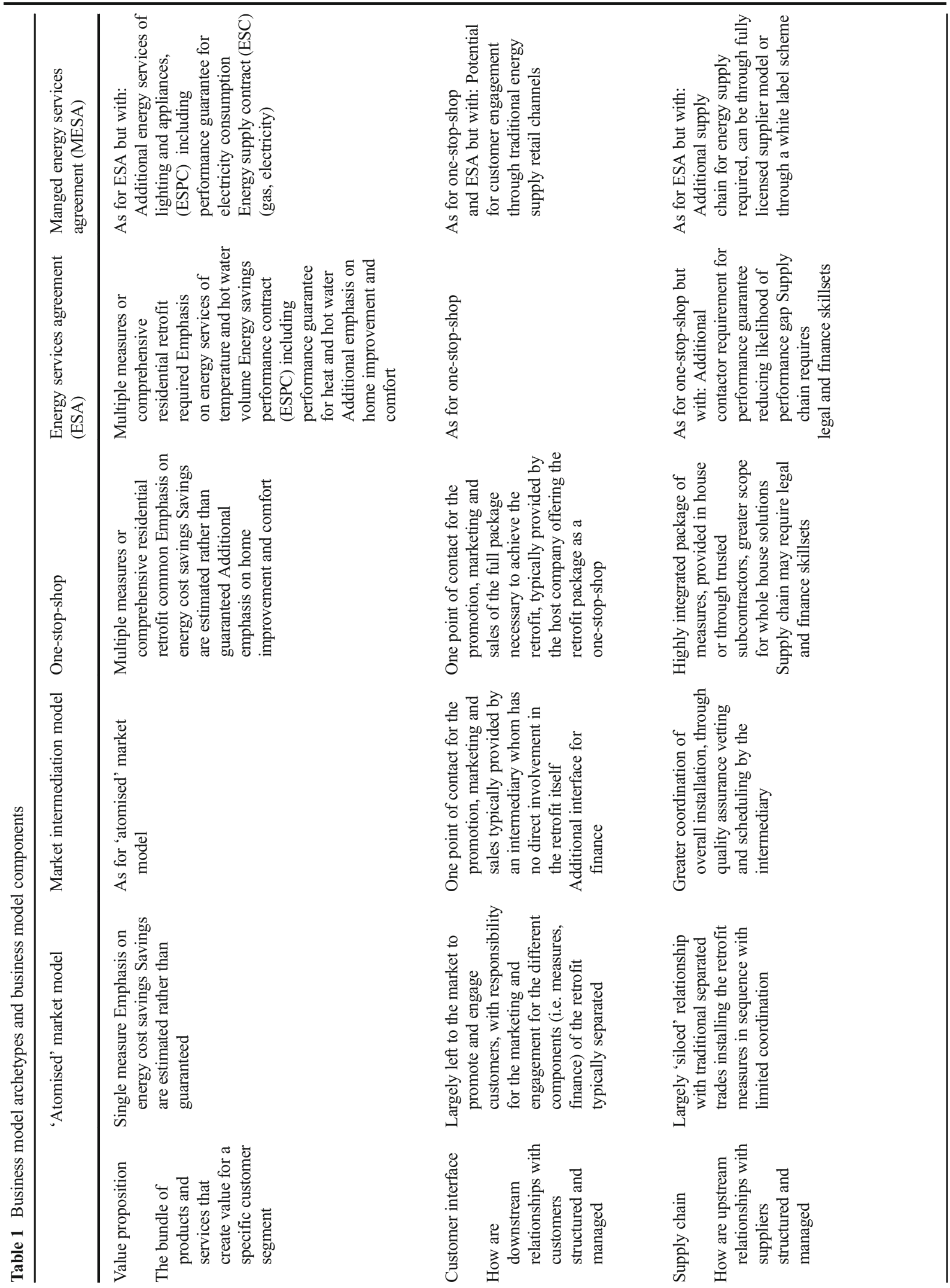




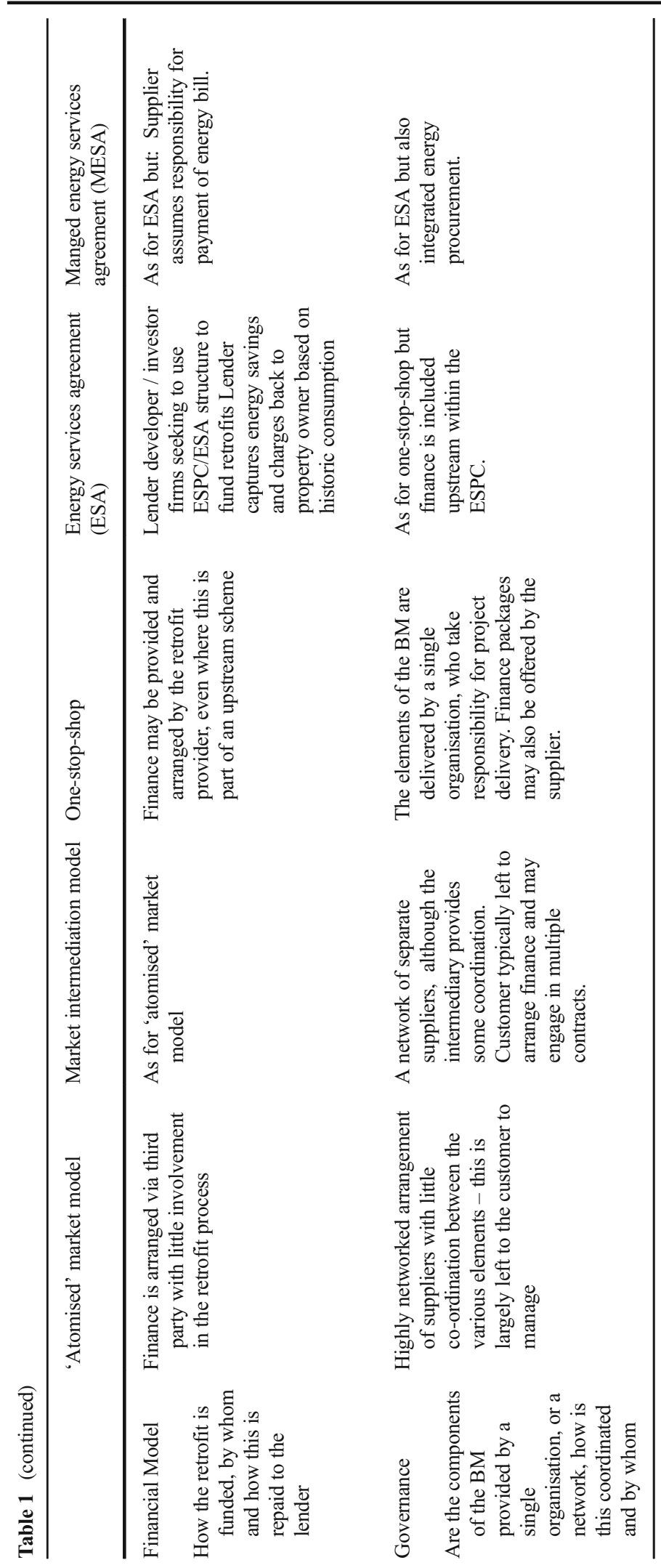


section . All these models currently exist in the EU, but some are much more widespread than others. The criteria for their differentiation were the five key BM components outlined in "Business model framework for residential retrofit" section.

The literature review was followed by scoping interviews with eight prominent experts in the residential retrofit field (see 'Expert scoping' in Table 3 appendix). The aim was to test the validity and representativeness of five archetypes and gain an overview of current practice in the UK and wider EU residential retrofit market. The selection of interviewees involved identification of the key organisations involved in the residential energy efficiency sector, including, academic, technical, advocacy and policy actors. Snowballing techniques were then used to develop contacts and source further interviewees (Kvale 2008).

Building on the insights from the expert interviews, the BM framework was refined, and an interview protocol developed for practitioners from each of the BM archetypes, with the aim of including at least two representatives of each archetype (see 'Practitioners' in Table 3). The sample was initially drawn from the UK but was expanded to include other EU Member States, including France, Latvia and the Netherlands, to obtain representatives of the more innovative and less common archetypes. The interview questions were designed to develop a detailed understanding of the structure and operation of the $\mathrm{BM}$ and how this influenced their success in delivering residential retrofit. Both sets of interviews were supplemented by documentary analysis of publicly available reports, where available.

Each interview was recorded, transcribed and coded using the NVivo $11^{\mathrm{TM}}$ software. This enabled detailed analysis of the responses, allowing common themes to be identified along with areas for further investigation. These methods were considered appropriate, given the need to develop a qualitative understanding of the role and importance of the different variables within in the BM framework, as well to test the validity of the archetypes through discussion with expert stakeholders (Kvale 2008). The use of several case studies for each archetype allowed identification of their commonalities and to control for more idiosyncratic elements. It is recognised that this method provides less granular detail than could be obtained from in-depth case studies and provides a less representative sample than could be obtained from a large survey. However, the chosen method is suitable for addressing the research questions given resource constraints.

\section{Retrofit business models: five key archetypes}

The following sections describe each of the five retrofit archetypes in turn. Each section provides examples of the archetype, identifies its distinguishing features and assesses how these characteristics influence the potential for delivering retrofits of residential buildings, particularly for more comprehensive approaches.

\section{‘Atomized’ market model}

The atomized market model continues to be the primary model delivering residential retrofit in the UK. Through an offering based on estimated energy cost and carbon savings, this model involves individual retrofit measures and technologies installed by separate contractors. Customers source the individual measures, energy audits and finance separately, with the result that multiple customer interfaces or points of contact are required for a comprehensive residential retrofit. The offer of energy savings is based on modelled impacts of measures, and no guarantees are provided. Therefore, any finance package is based on estimated rather than guaranteed cost savings. The details of the model are illustrated in Fig. 1.

Whilst a highly fragmented and market-based BM is the norm for many industries, interviewees agreed that this 'siloed' approach does not work well for comprehensive residential retrofit.

"[Supply chain integration] is extremely poor; there has been a focus on single measures for the last 20/25 years. It is going to be hard to make the shift to a more comprehensive approach. Single measures have their place, but you want to have mechanisms to do more comprehensive residential retrofit." (Academic - energy efficiency policy)

This focus on single measures stems directly from the atomised and uncoordinated nature of the dominant model; 
Fig. 1 The 'atomized' market model

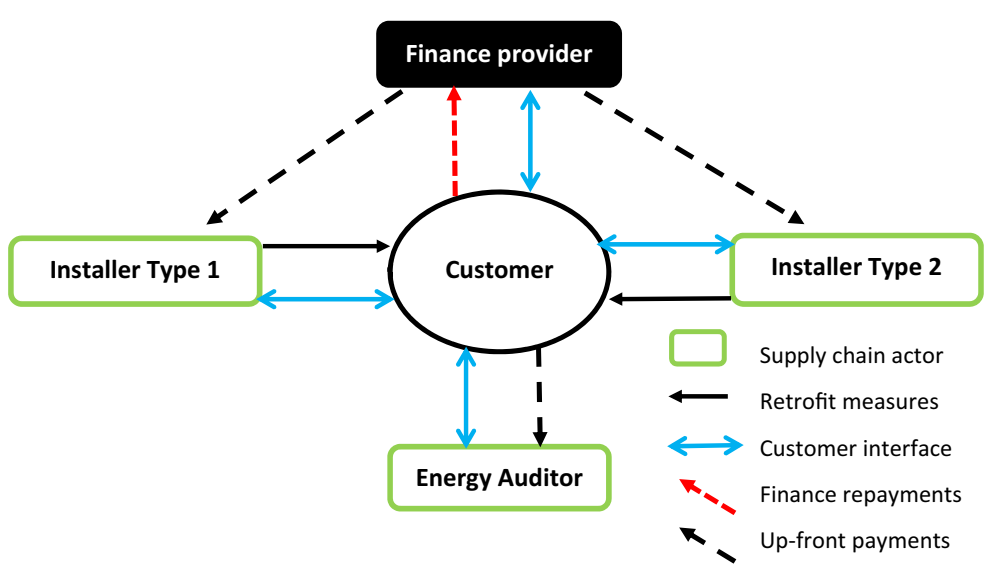

"what we've got in the UK is where the customer has to be this project manager...That's complex, it might work; for ringing somebody up when you boiler breaks down...[but] it's not the route for a... ramping up [of] energy efficiency measures" (Energy Saving Trust)

Such an approach has typified the delivery of the energy efficiency measures required and subsidised by UK policy, such as the Supplier Obligations and Green Deal, as well as the low-carbon heat measures subsidised by the Renewable Heat Incentive (RHI) and microgeneration Feed In Tariff (FIT). Thus, this approach has resulted in very few comprehensive residential retrofits - instead tending to deliver a succession of piecemeal interventions at different times, linked to an ever-evolving policy landscape.

"We have tended to focus in the UK on subsidy... installers, who do one thing; you can get a grant for doing $x$ measures, get some carbon credits from the energy company... and that's it. They don't care about how it performs, they don't care about how it actually impacts on the end user, they just go in and install one measure." (Policy Advisor - UKGBC)

This model has not helped develop an effective supply chain for residential retrofit, particularly for SWI, which requires a more comprehensive approach involving additional measures such as ventilation and draught proofing.

"I've been around probably now over 3000 houses that have had external wall insulation and I haven't seen any done right, and that is a fairly damning indictment of the industry...You have got industry-standard details which introduce cold bridging. There is no assessment of ventilation it is almost inevitable it's going to go wrong." (Director - BRE)

Market intermediation model

The market intermediation model, shown in Fig. 2, is also a relatively common delivery model for residential retrofit in the UK and the EU. This model usually involves the implementation of government subsidy schemes, focused on single measures and uses estimates of the associated energy cost and carbon savings from a basic energy audit. However, a key difference is the role of an intermediary organisation, who coordinate the supply chain and provide the customer interface through marketing activities and project management, thus, simplifying the customer journey. These schemes typically involve a Local Authorities (LA) or NGOs who offer information, consultancy and procurement guidance to the client and may also offer a range of specialist services and financing assistance. If the intermediary is trusted by potential customers, their involvement can lower transaction costs, facilitate project implementation and help raise awareness of retrofit opportunities in the residential sector, building upon existing trusted relationships at the area or community level.

UK examples of this model include the RE:NEW scheme implemented by the Greater London Authority (GLA), the Birmingham Energy Savers (BES) scheme, involving a partnership between Birmingham City Council and Carillion2 $\mathrm{F}^{7}$ and the Nottingham Energy

\footnotetext{
${ }^{7}$ A large international construction firm, headquartered in the UK
} 
Fig. 2 Market intermediary model

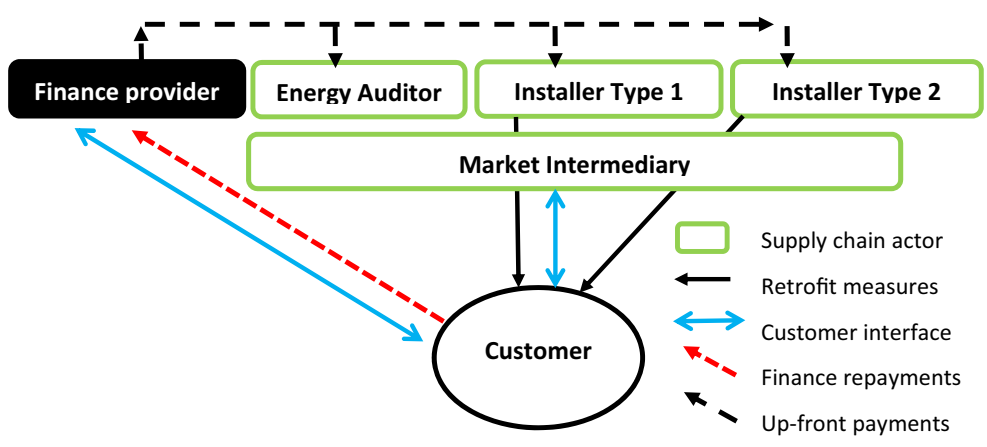

Partnership (NEP) an NGO initiative in Nottingham. These schemes commonly utilise relationships with local housing providers and LAs. The RE:NEW scheme has focussed on the social housing sector and has facilitated the retrofit of over 127,000 London homes, saving around $46 \mathrm{k}$ tonnes of carbon dioxide a year (GLA 2017). The NEP scheme focuses on the privately owned and rented sector, with an emphasis on households in fuel poverty. Both these schemes owe their success to the trusted relationships between households and their housing provider, or council; "working with the LA, it's that trusted brand" (Retrofit Intermediary).

By contrast, the large-scale BES scheme was a major failure. This is in part attributed to the use of a multinational private sector partner for the marketing and delivery of measures to households, rather than using the councils branding and a local SME supply chain (Watson 2014); "There [was] a lot of installers who don't deserve trust, I wouldn't touch them with a bargepole" (Sustainability Consultant - BES).

RE:NEW has supported additional carbon savings above and beyond what would have otherwise occurred in the delivery of government and business-as-usual planned programs. "The majority of organisations fed back [Its been] faster, deeper and with less risk involved" (Manager- RE:NEW - GLA).

However, these programs have done little to alter the underlying model of the industry and encourage the development of comprehensive residential retrofit with an integrated supply chain; "[in the end] it reverted to the piecemeal offer that we've identified is the problem" (Sustainability Consultant - BES). The reliance on national subsidy schemes, where "changes in policy mean that [the] model is ever changing" (Retrofit Intermediary), also means that there is very little retrofit activity once these schemes have ended. This stop-start nature of funding is a key factor in the lack of a well-developed supply chain for comprehensive residential retrofit in the
UK. This may be changing, with schemes such as RE:NEW looking to support more novel value propositions and longer term finance models (e.g., the Energiesprong approach discussed below). It was argued that whilst future retrofit policy programs should recognise the importance of long-term industry led solutions, "there is always going to be a role for intermediaries" (Academic - energy efficiency policy) even where integrated BMs are adopted.

One-stop-shop

The one-stop-shop BM (Fig. 3) involves an integrated supply chain and customer interface that provides a single point of contact for the customer. The supplier offers a 'holistic' design and build including a comprehensive package of services, a more extensive modelling and design phase, the production of a comprehensive residential retrofit plan and the implementation of multiple complementary measures. Delivery of these is coordinated through either a single company or a wellintegrated network of subcontractors. As shown in Fig. 3, some BMs also include finance as part of the offer, whilst several operate as cooperatives. The cooperative approach typically involves both suppliers and households as coop members, who receive dividends on their equity investment in retrofit projects.

Although more established in Scandinavia (Mahapatra et al. 2013; Straub 2016), the UK examples of this BM include the Retrofitworks project that utilises an online portal and cooperative approach to link suppliers to customers looking for retrofit and home auditing services through its sister company Parity Projects. The Brighton and Hove Energy Services Co-op (BHESCo) also uses a cooperative approach and a lowcost financing offer based on issuing shares to the local community. A key emphasis in the BM is a focus on the needs of the client and a simplification of the customer 
Fig. 3 One-stop-shop

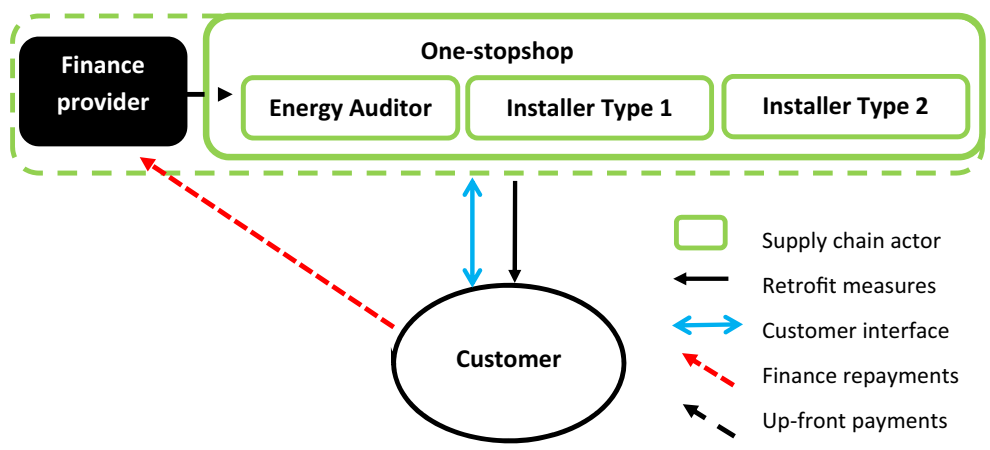

journey. Segel AS is a consultancy providing specialist guidance on the implementation of one-stop-shops in continental Europe and Scandinavia;

"The value proposition...... is a holistic retrofitting and single point of contact, easiness in the project, and project management...many of them also include help for the client in the application for grants... and confidence that the solutions chosen are right for [them]" (Segel AS - Business Consultant)

This approach typically facilitates comprehensive residential retrofits and may be applied in conjunction with other forms of renovation. In several of the Scandinavian examples, local SMEs collaborate with a larger company such as Bravida $3 \mathrm{~F}^{8}$ or national hardware chains a means of generating customers. In the case of Retrofitworks, the online portal is a key part of the customer interface where members of the cooperative can advertise works and have bids placed by the supply chain who are also cooperative members. Key to the success of these BMs is the role of specialist retrofit coordinators or project managers;

"a person who understands what every element of the good retrofit looks like; isn't an expert in all of them but knows when they look dodgy or when an expert is needed to be brought in on certain things. So is about the genuine coordination...so I am a massive advocate of that and its built-in within... Retrofitworks." (Retrofitworks/Parity Projects)

Whilst not all these examples offer financing, BHESCo combines their retrofit offering with a

\footnotetext{
${ }^{8}$ Bravida is an installation and service company with about 9000 employees at more than 160 locations in Sweden, Norway, Denmark and Finland.
}

community share issue to provide a financing package to its customers.

"It's based on this virtuous circle, you become a member of the co-op ... you invest...,you get a $5 \%$ return on investment. We invest your money into... energy efficiency, the customer pays from the savings in their energy bill" (BHESCo)

At present, the model is based on a hire purchase agreement $4 \mathrm{~F}^{9}$ or what may be termed a capital lease, with the assumption that if the person moves, they will see uplift in its value that will enable the lease to be paid off. However, offering competitive financing remains a challenge with considerable risk.

"Our...cost of capital is 5\%, but we may have to consider whether we can offer that in the future... its very tricky and very difficult [to offer competitive finance]" (BHESCo)

\section{Energy services agreement (ESA)}

The ESA involves a form of ESPC, where building occupants are provided with an energy performance guarantee for specific energy services, usually over a period of 15 years or more. Instead of paying for units of heating fuel, occupants are guaranteed a level of performance such as a specified internal temperature (i.e. $2{ }^{\circ} \mathrm{C}$ ) and a certain volume of hot water at a specified temperature. Such an approach is synonymous with the ESCO model in that measures and the subsequent guarantee are provided by an ESCO, who are

\footnotetext{
${ }^{9}$ Under an HP agreement, the debtor hires the goods and then pays an agreed amount by instalments. Whilst still making payments, the debtor is not allowed to sell or dispose of the goods without the lender's permission.
} 
Fig. 4 Energy services agreement (ESA)

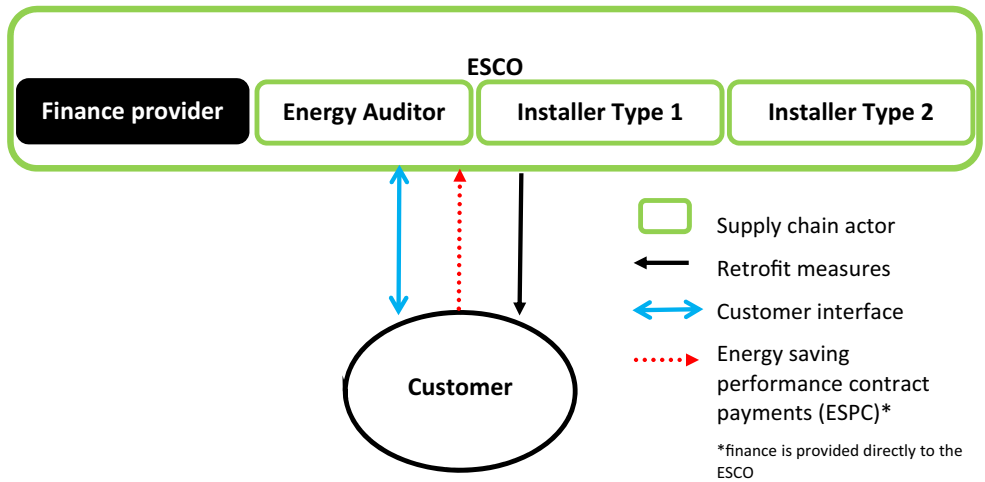

ESCO engaged as part of a long-term contract, with contractual penalties for under-performance. However, this model differs from the more common examples in the public and municipal sectors (where the debt for the retrofit measures is taken on by the building occupants or tenant) ${ }^{10}$ as measures are financed directly by the ESCO or upstream through a third party financier5F (The Rockefeller Foundation and DB Climate Change Advisors 2012). These projects typically consist of an integrated offering, covering a comprehensive residential retrofit of building fabric and heating measures, by a well-coordinated supply chain with design, build and operate phases under one contract. A comprehensive residential retrofit is a likely pre-condition to offering a temperature guarantee, thus ensuring modelled savings are realised and energy consumption is controlled (Fig. 4).

The review did not identify any examples of ESA contracts for residential retrofit in the UK, but examples exist in France and Latvia. The French state-owned railway company SNCF also manages a significant number of social housing properties under its subsidiary; ICF Habitat. ICF has undertaken several schemes based on an ESA model, focused on medium-to-highdensity multifamily buildings. The Energies POSIT'IF is an ESA model for privately owned or rented multifamily buildings in greater Paris. In addition, RENESCO is a social enterprise involved in the retrofit of dilapidated multifamily buildings in former Sovietera housing in Eastern Europe, particularly Latvia.

The Latvian example is notable for its value proposition involving a focus on structural improvement as a selling point.

\footnotetext{
${ }^{10}$ After significant desk-based and interview research, the author could not find any examples of this BM in the UK or EU residential retrofit sector - thus, it is excluded from the paper.
}

"We are not just conserving energy, our main task is conserving the building, we are protecting the building from the elements...about $15 \%$ of our total investment has nothing to do with energy efficiency" (RENESCO).

The risk of offering the ESPC is mitigated through a well-integrated BM "This was possible because of one entity taking a decision and co-ordinating the investments [and works]" (RENESCO). Such an approach means a single point of contact and recourse for the client: "the main advantage of the [ESPC contract] is that we have only one firm to talk to" (ICF Habitat). The successful coordination of the model therefore relies heavily on the design of effective contracts; "we as a buyer have to make them talk together, so we have to design a process"' (ICF Habitat).

An important component of the ESA model is the "bridge of finance and technology" (RENESCO). Under the ICF Habitat model, the capital is supplied by the housing provider, with the financial agreement upstream from the tenant. Whilst a large semi-public actor such as ICF can borrow at a relatively low cost of capital, RENESCO must source funds in private capital markets. RENESCO have chosen to use 'on balance sheet' finance, meaning the debt obligation is tied to the firm rather than the building owner. Based on their current cost of capital, "the renovation can be paid by the energy efficiency alone in 15 years" (RENESCO). However, the economics of their offering are very sensitive to the financing terms and the size of their portfolio. Therefore, RENESCO "hope to sell off the cashflows of the first 15 buildings" under a forfeiting scheme they are developing in collaboration with the European Bank for Reconstruction and Development (EBRD). This means that RENESCO can shift successful projects off their balance sheet and sell them on to investors in 
Fig. 5 Managed energy services agreement (MESA)

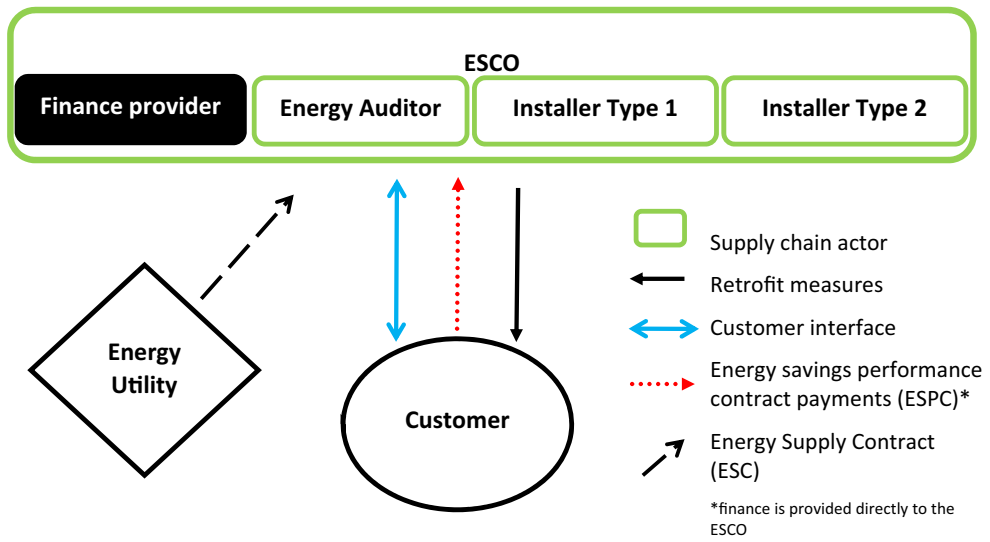

secondary markets, improving their borrowing conditions "So, we get our equity back, we have our capital back, we can pay back the loan, we hopefully make a little bit of a profit" (RENESCO).

\section{Managed energy services agreement (MESA)}

The MESA model (Fig. 5) is like the ESA approach in that the ESCO provides guarantees for the energy performance of plant and building fabric measures, installed during a retrofit (Kim et al. 2012). However, in the MESA model, the contracting organisation also takes on responsibility for the payment of the energy bill in an energy supply contract (ESC) upstream of the customer; to provide total energy management. This requires additional capability in energy supply and procurement. This also introduces a potential role for renewable electricity, storage and demand side management as part of the MESA. This level of integration also incentivises an integrated supply chain and represents a holistic energy services offering to the customer.

Whilst the MESA is more common in the commercial or public sector, the Dutch government has funded a large-scale trial of this approach in the social housing sector, known as the Energiesprong or 'energy leap' initiative (Energiesprong 2014). The scheme has thus far delivered approximately 1800 comprehensive residential retrofits in the Netherlands, largely focusing on single family semi-detached or terraced units. At the time of writing the first UK trial is about to commence in Nottingham (Energiesprong 2017). This is the only known example of a MESA in the EU residential sector.

Energiesprong do not deliver the measures or the guarantee but instead their market development team acts as an intermediary between the client and contractor, providing technical assistance in implementation. Customers are offered a comprehensive residential retrofit, based upon net-zero energy consumption. Typically, an Energiesprong retrofit involves the delivery of off-site manufactured, insulated facades, integrated with renewable heat systems and PV panels as well as lighting and controls. The contractor offers a 30 -year energy performance guarantee for net-zero annual energy consumption, amortised over the calendar year. This is based on a guaranteed internal temperature of $21^{\circ} \mathrm{C}$ in living spaces and a set allowance of hot water and electricity consumption, akin to a mobile phone contract with usage limits. A comprehensive residential retrofit, with electricity microgeneration, is a likely precondition to offering a net-zero energy guarantee, ensuring modelled savings are realised and heat and electricity consumption are controlled.

"The main premise of Energiesprong is an outcome-based procurement approach, specifying what it needs to do for the next 30 years; a long list of energy related measures; comfort, health and quality elements. So therefore, our approach is entirely technology agnostic" (Energiesprong UK)

Again, the value proposition emphasises the health, comfort and aesthetic benefits, ahead of energy cost savings.

"The quality of the design- the 'kerbside appeal' of the refurbished property...It is a complete envelope, so it gives an opportunity to redesign the property and uplift the value, not because of the energy efficiency economics, but the design improvements of the property" (Energiesprong UK) 
The aim is to create demand through a desirable customer offering;

"it was new, it was exciting, and everybody looked at it. You had owner occupiers knocking on the door and saying, "Can I buy one of those?" So, it is really being able to see, to display the product, which is a brand new refurbished house" (Energiesprong UK)

The Energiesprong model requires significant process innovation, in the form of developing entire insulated facades using offsite manufacture techniques, to enable an installation time of less than 1 week. This process of mass production and industrialisation is key to enabling ESPCs for single family dwellings. Such an industrialised approach also drives down costs for SWI, which would otherwise be prohibitively expensive.

"So therefore, it is a challenge given to industry... because there is no technical specification, but an outcome-based specification it is more [like] a product design approach in industry; akin to automotive and other sectors." (Energiesprong UK)

The Energiesprong MESA has thus far been applied in the social housing sector, and "the financing model therefore is a combination...of maintenance, major repair works. And the additional revenue stream for thirty years from the energy plan that comes with the property." (Energiesprong UK). However, at present, the net-zero energy retrofit is too expensive to enable a payback within the 30-year contact. "The [current] market price for a 3-bed terraced property of $80 \mathrm{~m}^{2}$ we would be looking at $£ 70 k$. As a starting point, maybe a trajectory to $£ 40 k$, $£ 35 k$ [is needed]". The Energiesprong UK team are hoping to build up a large order-book that would enable industrialisation of the supply chain and economies of scale. Currently, the model is reliant on several sources of grant funding including the EU Interreg scheme. However, for long-term economic viability, a cost of capital at $<2 \%$ is also likely to be required.

\section{Summary of findings}

A summary of the five archetypes and how they differ in terms of the BM components is provided in Table 1. The results of the empirical study have provided insights into the characteristics of successful retrofit BMs, including some generalisable findings that drawn lessons from all five archetypes, summarised in Table 2.

\section{Discussion}

The preceding sections have identified five BMs for the delivery of residential retrofit and evaluated the potential of these models based on recent cases in the UK and EU. Previous studies discuss the emergence of one-stopshop BMs for single family homes (Mahapatra et al. 2013) and the potential of ESCO models in this sector (Moschetti and Brattebø 2016; Winther and Gurigard 2017), but have provided few empirical examples. This study builds on this work through identifying the energy service agreement (ESA) and managed energy service agreement (MESA) models involving residential ESPCs, along with the market intermediation model. These are contrasted with the incumbent 'atomized' market model that typifies most residential retrofits in the UK and EU. The study thus contributes to the literature on residential retrofit by identifying and evaluating the broader range of BMs in this area.

The findings in Table 2 support the argument that ESPCs have a significant potential for energy saving in residential buildings (Steinberger et al. 2009). In addition, the study demonstrates the importance of an emphasis on comfort, health and well-being and the improved condition of the property as per the value proposition (Pätäri and Sinkkonen 2014; Sunikka-Blank and Galvin 2016). Supply chain integration (where multiple measures and design services are provided by a single organisation) is shown as critical for the delivery of comprehensive residential retrofit, particularly for single-family houses. This supports previous literature on one-stop-shop retrofit BMs (Mahapatra et al. 2013; Mlecnik et al. 2012). Through this more integrated approach, performance gaps (Dowson et al. 2012) and negative unintended consequences, such as mould and poor air quality, can also be minimized (Hansford 2015). In turn, this can strengthen the reputation of the industry and further simplify the customer journey. This contrasts with the highly fragmented and 'siloed' supply chains that have characterised most residential retrofit delivery to date.

The inclusion of financing options as part of the retrofit package may also be a critical driver. Whilst many UK suppliers are unable to provide financing, the more integrated businesses models, such as BHESCo and the ESA and MESA models, include 
Table 2 Main findings and application of business model framework

\begin{tabular}{|c|c|}
\hline Business model component & Key findings \\
\hline $\begin{array}{l}\text { Value proposition: what value is embedded in the product/service } \\
\text { offered by the firm }\end{array}$ & $\begin{array}{l}\text { - Value proposition should place less on emphasis on carbon and energy } \\
\text { cost savings. Focus instead on comfort, health benefits, aesthetics, } \\
\text { building longevity and uplift in value } \\
\text { - Energy performance guarantees can be more attractive to customers and } \\
\text { can help reduce performance gaps, although they add risk and cost for } \\
\text { contractors }\end{array}$ \\
\hline $\begin{array}{l}\text { Supply chain: how are upstream relationships with suppliers, } \\
\text { structured and managed }\end{array}$ & $\begin{array}{l}\text { - Integrated supply chains can improve quality and reduce unintended } \\
\text { consequences, but the required holistic skillset is lacking in the UK due } \\
\text { to highly 'siloed' disciplines } \\
\text { - The role of a retrofit coordinator may therefore be an essential } \\
\text { component for the successful delivery of comprehensive residential } \\
\text { retrofit }\end{array}$ \\
\hline $\begin{array}{l}\text { Customer interface: how are downstream relationships } \\
\text { with customers, structured and managed }\end{array}$ & $\begin{array}{l}\text { - A single and trusted point of contact is very important, particularly for } \\
\text { single family schemes } \\
\text { - Cooperative and community-based approaches offer a key means of } \\
\text { customer engagement for retrofit } \\
\text { - Integrated supply chain or one-stop-shops can help but general lack of } \\
\text { awareness of retrofit and customer engagement at all levels }\end{array}$ \\
\hline $\begin{array}{l}\text { Financial model: the nature of operational expenditures, and the } \\
\text { means of revenue generation from the business activities }\end{array}$ & $\begin{array}{l}\text { - Low cost of capital is essential for the viability of long-term } \\
\text { comprehensive approaches due to the low rates of return } \\
\text { - Energy performance guarantees can reduce perceived risk for investors, } \\
\text { and thereby lower cost of capital } \\
\text { - An integrated financing package provided with the retrofit is also likely } \\
\text { to encourage customer demand }\end{array}$ \\
\hline $\begin{array}{l}\text { Governance: coordinating the BM may involve a multi actor } \\
\text { network; spanning multiple organisations }\end{array}$ & $\begin{array}{l}\text { - Successful retrofits involve the coordination of the various elements of } \\
\text { the BM; this helps both suppliers and customers } \\
\text { - Networked approaches such as the 'atomized' market model are only } \\
\text { suitable for single measures. Comprehensive residential retrofit is } \\
\text { better delivered through integrated BMs; where the supply chain, } \\
\text { customer interface and financial model are brought together as a } \\
\text { coordinated offering } \\
\text { - The role of intermediary organisations, i.e. municipalities or } \\
\text { cooperatives likely to be crucial, particularly for novel BMs }\end{array}$ \\
\hline
\end{tabular}

long-term finance packages to cover the up-front cost of measures. However, the associated cost of capital is critical in determining the economic viability of comprehensive residential retrofit measures such as SWI (Gouldson et al. 2015). Indeed, the Energiesprong model is currently reliant on several forms of grant funding for its economic viability. Whilst the existence of an ESPC is likely to reduce the perceived risk for investors, several other factors will also be important (Donovan and Corbishley 2016).

Low customer demand is perhaps the biggest challenge for the upscaling of whole-house retrofit. A lack of visibility and knowledge of retrofit measures can be a key barrier (Marchand et al. 2015), as well as the hassle for the occupants (Snape et al. 2015). Indeed, retrofit interventions may also affect current practices in the home (such as heating behaviour), the inherent qualities of the property and other competing needs and desires (Gram-Hanssen 2014; Wilson et al. 2015). Retrofit measures are not typically differentiated from other renovation decisions (Wilson et al. 2015). Thus, other renovations (such as bathroom replacement) may present opportunities for retrofit at certain points in a properties' life cycle (Achtnicht and Madlener 2014). Occupants may also balance potential economic benefits of retrofits against building heritage and aesthetic concerns (Sunikka-Blank and Galvin 2016).

This study shows that a BM with a simplified customer interface, with one point of contact for the retrofit process, reduces this complexity and may address barriers to uptake (Mahapatra et al. 2013). Examples, such as the Energiesprong scheme, utilise industrialised processes to 
reduce retrofit timescales and the visual upgrade of external facades, and could drive increased demand through 'kerbside appeal'. The role of intermediaries or facilitators may be particularly important in promoting the uptake of novel BMs (Bleyl et al. 2013), involving coordinated marketing efforts, capacity and trust building with energy agencies, supply chains, LAs, and the media (Long et al. 2015; Stieb and Dunkelberg 2013).

If the $\mathrm{BM}$ is characterised as the network through which the product or service is delivered, the governance of this network becomes critical. This builds on other work that identifies the role of network governance in delivering energy service BMs (Hellström et al. 2015). The findings suggest that integrated BMs are likely to be most suitable for comprehensive residential retrofit, where the individual components of the $\mathrm{BM}$ are coordinated by a single actor to provide a simple and holistic offering to the customer.

At present, these innovative BMs are relatively rare, with the ESA and MESA models largely being trialled in multifamily buildings and social housing. With the UK's large share of private rented, owner occupier and singlefamily housing (Element Energy 2013), a significant challenge remains to scale up these models to impact the wider residential market. In the MESA example in this study, the ESPC is included into the rental agreement. In the owner occupier sector, this would supplant the energy supply contract and would therefore require alterations to UK legislation surrounding the energy switching rights of consumers (Ofgem 2016). The Dutch Energiesprong policy aimed to address the retrofit challenge and produce BM innovation (Energiesprong 2017). This included a range of regulatory changes, public funding commitments and the establishment of a 'market development team', to promote a radical shift in industry practice (Energiesprong 2017). Highlighting that a mix of policy solutions may be required to overcome the multifaceted challenges of comprehensive residential retrofit and promote $\mathrm{BM}$ innovation.

This paper described the breadth of BMs adopted for residential retrofit, including novel and innovative examples, using desk-based research and qualitative interviews. Whilst this approach enabled a detailed understanding of each archetype, the smaller number of participants involved means the results are harder to generalise than quantitative results. The pre-testing of the framework with 'experts' was intended to prevent key approaches and elements being missed; although it is acknowledged, this could introduce selection bias in the choice of interviewees. Equally, the use of in-depth case studies would have provided greater depth of understanding for specific approaches, at the expense of breadth. However, acknowledging these weaknesses, the approach adopted provides a balance between these factors and is deemed appropriate for the research aims.

\section{Conclusions}

This paper has demonstrated how BMs can be a useful framework for understanding the challenges posed by residential retrofit. The paper has identified five archetypes that are currently being used for residential retrofit within the EU, compared them in terms of their value proposition, supply chain, customer interface and financial model and overall BM governance and showed how differences in these elements can help explain their relative potential in delivering comprehensive residential retrofit.

The paper has shown how more innovative BMs could expand the market for comprehensive residential retrofits in the UK. Elements of a successful BM include the following:

- A value proposition focussed primarily upon aesthetics, comfort, health and well-being and includes guaranteed rather than estimated energy performance savings

- An integrated and industrialised supply chain providing a comprehensive whole-house approach

- A simplified customer interface with a single expert point of contact

- A financial model that includes a low-cost financing mechanism integral to the offering

- Coordinated governance of these four components through an integrated BM

This is in stark contrast to the highly 'atomized', market-oriented approach adopted as the primary UK delivery model to date.

Two issues in particular merit further research. First, the nature of the finance mechanism remains a key challenge, so further research should aim to identify how alternative mechanisms could enable long-term finance with a low cost of capital. Second, future work should identify the challenges of BM innovation in the sector, the barriers to such innovation and how both industry and policymakers can respond to these challenges. 
There are multiple gains from comprehensive residential retrofit, including health and economic benefits that go beyond energy and carbon savings. This paper has shown how viewing this challenge through the lens of BMs can provide valuable new insights. What is clear is that the incumbent approach is not delivering the scale of change needed, which necessitates the rapid growth in comprehensive whole-house retrofit in a short period. Meeting ambitious carbon targets requires a sea change in the industry and the diffusion of innovative BMs, such as those outlined in this paper. Achieving this will require new ways of thinking in both industry and policy.

Acknowledgements I would like to thank Steve Sorrell, Paula Kivimaa, Bill Brown and four anonymous reviewers who all provided helpful comments on earlier drafts of this manuscript.

Funding information This research was funded by the United Kingdom's Engineering and Physical Sciences Research Council (EPSRC) through a grant to the Centre on Innovation and Energy Demand (CIED), Ref. EP/K011790/1.

\section{Appendix}

Table 3 Interview details

\begin{tabular}{|c|c|c|}
\hline BMBM archetype & Organisation & Actor \\
\hline \multicolumn{3}{|l|}{ Expert scoping } \\
\hline \multirow[t]{8}{*}{ All } & University of Oxford & $\begin{array}{l}\text { Senior Research Fellow - energy } \\
\text { efficiency policy }\end{array}$ \\
\hline & United Kingdom Green Building Council (UKGBC) & Policy Advisor \\
\hline & Energy Saving Trust (EST) & Senior Insight Manager \\
\hline & Building Research Establishment (BRE) & Director (Wales) \\
\hline & Energy Programs Consortium & $\begin{array}{l}\text { Counsel and Director of Finance } \\
\text { Programs (USA) }\end{array}$ \\
\hline & Buildings Performance Institute Europe (BPIE)/Reshape innovation & $\begin{array}{l}\text { Innovation Strategist - Founder } \\
\text { (Reshape Innovation) }\end{array}$ \\
\hline & Georgia Institute of Technology (USA) & Professor of Energy Policy \\
\hline & Association for Environmental Studies and Sciences (AESS) & Principal and Independent Consultant \\
\hline \multicolumn{3}{|l|}{ Practitioner } \\
\hline \multirow[t]{2}{*}{ Atomized market model } & Building Research Establishment (BRE) & Director (Wales) \\
\hline & Sustainable Design Collective & Architect - Managing Director \\
\hline \multirow[t]{3}{*}{ Market intermediary model } & Greater London Authority (RE:NEW) & Program Manager -Energy \\
\hline & Nottingham Energy Partnership & Contracts Manager \\
\hline & Birmingham Energy Savers (BES) (Consultant) & Sustainability Consultant \\
\hline \multirow[t]{3}{*}{ One-stop-shop } & Retrofit works/Parity projects & Director \\
\hline & Segel AS - Norway & Business Development Consultant \\
\hline & Brighton and Hove Energy Services Company (BHESCo) & CEO \\
\hline \multirow[t]{3}{*}{ ESA } & Energies POSIT'IF - Paris France & $\begin{array}{l}\text { Innovation Strategist - Founder } \\
\text { (Reshape innovation) }\end{array}$ \\
\hline & ICF Habitat- Paris France & Head of Energy \& Water \\
\hline & RENESCO - Riga, Latvia & Managing Director \\
\hline MESA & Energiesprong - UK, Netherlands & Project manager/Rainmaker \\
\hline
\end{tabular}


Open Access This article is distributed under the terms of the Creative Commons Attribution 4.0 International License (http:// creativecommons.org/licenses/by/4.0/), which permits unrestricted use, distribution, and reproduction in any medium, provided you give appropriate credit to the original author(s) and the source, provide a link to the Creative Commons license, and indicate if changes were made.

\section{References}

Achtnicht, M., \& Madlener, R. (2014). Factors influencing German house owners preferences on energy retrofits. Energy Policy, 68, 254-263. https://doi.org/10.1016/j. enpol.2014.01.006.

Amit, R., \& Zott, C. (2001). Value creation in E-business. Strategic Management Journal, 22(6-7), 493-520. https://doi.org/10.1002/smj.187.

Bertoldi, P., Hinnells, M., \& Rezessy, S. (2006). Liberating the power of Energy Services and ESCOs in a liberalised energy market. In Proceedings of the EEDAL 2006 Conference. London, UK.

Bleyl, J. W., Adilipour, N., Bareit, M., Bourgois, C.-H., \& Vanstraelen Fedesco Knowledgecenter, L. (2013). ESCo market development: a role for Facilitators to play. In ECEEE Summer Studies (pp. 3-472). Belambra Presqu'île de Giens, France. Retrieved from http://www. kompetenzzentrum-contracting.de/fileadmin/uploads redaktion/PDF/Literatur_Download/IEADSMTask XVI_eceee papers No. 3-472-13 ESCo Facilitator $130322^{-}$ pdf.

Bleyl-Androschin, J., \& Schinnerl, D. (2007). Comprehensive refurbishment of buildings with energy services. In ECEEE 2007 summer study. Saving energy-Just do it! 817 (pp. 817-828). Retrieved from http://edit.eceee. org/library/conference_proceedings/eceee_Summer_ Studies/2007/Panel_5/5.039/paper

Bolton, R., \& Hannon, M. (2016). Governing sustainability transitions through business model innovation: towards a systems understanding. Research Policy, 45(9), 1731-1742. https://doi.org/10.1016/J.RESPOL.2016.05.003.

Boons, F., \& Lüdeke-Freund, F. (2013). Business models for sustainable innovation: state-of-the-art and steps towards a research agenda. Journal of Cleaner Production, 45, 9-19. https://doi.org/10.1016/j.jclepro.2012.07.007.

Boons, F., Montalvo, C., Quist, J., \& Wagner, M. (2013). Sustainable innovation, business models and economic performance: an overview. Journal of Cleaner Production, 45, 1-8. https://doi.org/10.1016/j.jclepro.2012.08.013.

Bradach, J. L., \& Eccles, R. G. (1989). Markets versus hierarchies: from ideal types to plural forms. Annual Review of Sociology, 15(Richardson 1972), 97-118. https://doi.org/10.1146 /annurev.so.15.080189.000525.

CCC. (2013). Committee on Climate Change. Fourth carbon budget review - part 2. Retrieved from https://www.theccc. org.uk/wp-content/uploads/2013/12/1785b-CCC_TechRep_ Singles_Book_1.pdf

CCC. (2015). The Fifth Carbon Budget - the next step towards a low-carbon economy-November 2015. Retrieved from https://www.theccc.org.uk/wp-content/uploads/2015/11 /Committee-on-Climate-Change-Fifth-Carbon-BudgetReport.pdf

CCC. (2016). Meeting Carbon Budgets-2016 Progress Report to Parliament. Retrieved from https://www.theccc.org. $\mathrm{uk} /$ publications/

DaSilva, C. M., \& Trkman, P. (2014). Business model: what it is and what it is not. Long Range Planning, 47(6), 379-389. https://doi.org/10.1016/j.lrp.2013.08.004.

Davies, M., \& Oreszczyn, T. (2012). The unintended consequences of decarbonising the built environment: A UK case study. Energy and Buildings, 46, 80-85.

De Groote, M., Lefever, M., \& Reinaud, J. (2016). Scaling up deep energy renovation unleashing the potential through innovation $\&$ industrialisation.

DECC (2015). Energy efficiency statistical summary 2015 Energy Efficiency Deployment Office.

Donovan, C., \& Corbishley, C. (2016). The cost of capital and how it affects climate change mitigation investment. Grantham Institute Briefing Paper, (15). Retrieved from www. imperial.ac.uk/grantham/publications

Dowson, M., Poole, A., Harrison, D., \& Susman, G. (2012). Domestic UK retrofit challenge: barriers, incentives and current performance leading into the Green Deal. Energy Policy, 50, 294-305. https://doi.org/10.1016/j.enpol.2012.07.019.

Duplessis, B., Adnot, J., Dupont, M., \& Racapé, F. (2012). An empirical typology of energy services based on a welldeveloped market: France. Energy Policy, 45, 268-276. https://doi.org/10.1016/j.enpol.2012.02.031.

Edrich, B., Beagley, K., Webber, P., \& Kelling, S. (2010). Kirklees warm zone final report 2007-2010, 25.

Element Energy (2013). Review of potential for carbon savings from residential energy efficiency. Retrieved from https://www.theccc.org.uk/wp-content/uploads/2013/12 /Review-of-potential-for-carbon-savings-from-residentialenergy-efficiency-Final-report-A-160114.pdf.

Energiesprong (2014). Transition Zero, 1-30.

Energiesprong (2017). United Kingdom-Energiesprong. Retrieved March 7, 2017, from http://energiesprong. eu/country/united-kingdom/.

Engelken, M., Römer, B., Drescher, M., Welpe, I. M., \& Picot, A. (2016). Comparing drivers, barriers, and opportunities of business models for renewable energies: a review. Renewable and Sustainable Energy Reviews, 60, 795-809. https://doi.org/10.1016/j.rser.2015.12.163.

Eriksson, P. E. (2008). Procurement and governance management: development of a conceptual procurement model based on different types of control. EconStor., 91, 558-564. https://doi. org/10.1007/s10273-011-1262-2.

EST (2011). Local authority large scale retrofit: a review of finance models. Retrieved from http://www.energysavingtrust.org. uk/Publications 2/Local-delivery/Funding-andfinance/Local-authority-large-scale-retrofit-A-review-offinance-models.

Foxon, T. J., Bale, C. S. E., Busch, J., Bush, R., Hall, S., \& Roelich, K. (2015). Low carbon infrastructure investment: extending business models for sustainability. Infrastructure Complexity, 2(1), 4. https://doi.org/10.1186/s40551-0150009-4.

Fylan, F., Glew, D., Smith, M., Johnston, D., Brooke-Peat, M., Miles-Shenton, D., Fletcher, M., Aloise-Young, P., \& Gorse, 
C. (2016). Reflections on retrofits: overcoming barriers to energy efficiency among the fuel poor in the United Kingdom. Energy Research \& Social Science, 21, 190-198. https://doi.org/10.1016/j.erss.2016.08.002.

Gauthier, C., \& Gilomen, B. (2016). Business models for sustainability: energy efficiency in urban districts. Organization \& Environment, 29(1), 124-144. https://doi.org/10.1177 $/ 1086026615592931$.

GLA. (2017). RE:NEW success | London City Hall. Retrieved March 7, 2017, from https:/www.london.gov.uk/what-wedo/environment/energy/renew-0/renew-success.

Gouldson, A., Kerr, N., Millward-Hopkins, J., Freeman, M. C., Topi, C., \& Sullivan, R. (2015). Innovative financing models for low carbon transitions: exploring the case for revolving funds for domestic energy efficiency programmes. Energy Policy, 86, 739-748. https://doi.org/10.1016/j. enpol.2015.08.012.

GOV.UK (2017). Standard Assessment Procedure - GOV.UK. Retrieved September 28, 2017, from https://www.gov. uk/guidance/standard-assessment-procedure.

Gram-Hanssen, K. (2014). Retrofitting owner-occupied housing: remember the people. Building Research \& Information, 42(4), 393-397. https://doi.org/10.1080 /09613218.2014.911572.

Guertler, P., \& Rosenow, J. (2016). Buildings and the 5th carbon budget. London.

Gupta, R., \& Chandiwala, S. (2010). Understanding occupants: feedback techniques for large-scale low-carbon domestic refurbishments. Building Research \& Information, 38(5), 530-548. https://doi.org/10.1080/09613218.2010.495216.

Hall, S., \& Roelich, K. (2016). Business model innovation in electricity supply markets: the role of complex value in the United Kingdom. Energy Policy, 92, 286-298. https://doi. org/10.1016/J.ENPOL.2016.02.019.

Hannon, M. J., \& Bolton, R. (2015). UK Local Authority engagement with the Energy Service Company (ESCo) model: key characteristics, benefits, limitations and considerations. Energy Policy, 78, 198-212. https://doi.org/10.1016/j. enpol.2014.11.016.

Hannon, M. J., Foxon, T. J., \& Gale, W. F. (2015). "Demand pull" government policies to support Product-Service System activity: The case of Energy Service Companies (ESCos) in the UK. Journal of Cleaner Production, 108, 1-16. https://doi. org/10.1016/j.jclepro.2015.05.082.

Hansford, P. (2015). Solid wall insulations: unlocking demand and driving up standards. London.

Hellström, M., Tsvetkova, A., Gustafsson, M., \& Wikström, K. (2015). Collaboration mechanisms for business models in distributed energy ecosystems. Journal of Cleaner Production, 102, 226-236. https://doi.org/10.1016/j. jclepro.2015.04.128.

Irrek, W., Suerkemper, F., Labanca, N., \& Bertoldi, P. (2013). ESCOs for residential buildings: market situation in the European Union and policy recommendations. ECEEE Summer Study Proceedings, 1339-1347.

Jankel, Z. (2013). Delivering and funding housing retrofit: a review of community models. Retrieved from http://www. instituteforsustainability.co.uk/uploads/File/Delivering and Funding Housing Retrofit report_March 2013.pdf.

Kangas, H.-L., Lazarevic, D., \& Kivimaa, P. (2017). Technical skills, disinterest and non- functional regulation: energy efficiency barriers viewed in an ecosystem of energy service companies. Energy Policy, 114, 63-76. https://doi. org/10.1016/j.enpol.2017.11.060.

Kats, G., Menkin, A., Dommu, J., \& Debold, M. (2011). Energy efficiency financing - models and strategies. Capital E.

Kelly, S., Crawford-Brown, D., \& Pollitt, M. G. (2012). Building performance evaluation and certification in the UK: is SAP fit for purpose? Renewable and Sustainable Energy Reviews, 16(9), 6861-6878. https://doi.org/10.1016/j. rser.2012.07.018.

Kim, C., O'Connor, R., \& Bodden, K. (2012). Innovations and opportunities in energy efficiency finance. Wilson Sonsini Goodrich \& Rosati. Retrieved from http://www.wsgr. com/publications/pdfsearch/wsgr-ee-finance-white-paper. pdf.

Kindström, D., \& Ottosson, M. (2016). Local and regional energy companies offering energy services: key activities and implications for the business model. Applied Energy, 171, 491500. https://doi.org/10.1016/j.apenergy.2016.03.092.

Kivimaa, P., \& Martiskainen, M. (2017). Innovation, low energy buildings and intermediaries in Europe: systematic case study review. Energy Efficiency, 11(1), 31-51. https://doi. org/10.1007/s12053-017-9547-y.

Knoeri, C., Steinberger, J. K., \& Roelich, K. (2016). End-user centred infrastructure operation: towards integrated end-use service delivery. Journal of Cleaner Production, 132, 229239. https://doi.org/10.1016/j.jclepro.2015.08.079.

Koh, L., Jones, C. R., Genovese, A., Acquaye, A., Marchand, R., \& Scott, F. (2013). Promoting the Green Deal to low income communities: initial insights from Yorkshire \& The Humber. Sheffield.

Kvale, S. (2008). Doing interviews. Sage.

Labanca, N., Suerkemper, F., Bertoldi, P., Irrek, W., \& Duplessis, B. (2014). Energy efficiency services for residential buildings: market situation and existing potentials in the European Union. Journal of Cleaner Production, 109, 284-295. https://doi.org/10.1016/j.jclepro.2015.02.077.

Lewis, J., \& Smith, L. (2013). Breaking the barriers: an industry review of the barriers to Whole House Energy Efficiency Retrofit and the creation of an industry action plan-Energy Efficiency Partnership for Buildings (EEPB) (Vol. 86).

Long, T. B., Young, W., Webber, P., Gouldson, A., \& Harwatt, H. (2015). The impact of domestic energy efficiency retrofit schemes on householder attitudes and behaviours. Journal of Environmental Planning and Management, 58(10), 18531876. https://doi.org/10.1080/09640568.2014.965299.

Lopez, F. J. D., Becker, J., Eris, B., Koers, W., \& Bastein, T. (2014). New business models that support resource efficiency.

Mahapatra, K., Gustavsson, L., Haavik, T., Aabrekk, S., Svendsen, S., Vanhoutteghem, L., Paiho, S., \& Ala-Juusela, M. (2013). Business models for full service energy renovation of singlefamily houses in Nordic countries. Applied Energy, 112, 1558-1565. https://doi.org/10.1016/j.apenergy.2013.01.010.

Mallaburn, P. S., \& Eyre, N. (2014). Lessons from energy efficiency policy and programmesin the UK from 1973 to 2013. Energy Efficiency, 7, 23-41. https://doi.org/10.1007/s12053013-9197-7.

Marchand, R. D., Koh, S. C. L., \& Morris, J. C. (2015). Delivering energy efficiency and carbon reduction schemes in England: lessons from Green Deal Pioneer Places. Energy Policy, 
84(January 2013), 96-106. https://doi.org/10.1016/j. enpol.2015.04.035.

Milin, C., \& Bullier, A. (2011). Energy retrofitting of social housing through energy performance contracts. A feedback from the FRESH project : France, Italy, United Kingdom and Bulgaria. FRESH (financing energy refurbishment for social housing).

Milsom, E. (2016). Solid wall heat losses and the potential for energy saving. Consequences for consideration to maximise SWI benefits: a route-map for change. Watford. Retrieved from www.bre.co.uk

Mlecnik, E., Kondratenko, I., Cré, J., Vrijders, J., Degraeve, P., Van Der Have, J. A., ... Paiho, S. (2012). Collaboration opportunities in advanced housing renovation. Energy Procedia, 30, 1380-1389. https://doi.org/10.1016/j. egypro.2012.11.152

Moschetti, R., \& Brattebø, H. (2016). Sustainable business models for deep energy retrofitting of buildings: state-of-the-art and methodological approach. Energy Procedia, 96(1876), 435445. https://doi.org/10.1016/j.egypro.2016.09.174.

Nolden, C., Sorrell, S., \& Polzin, F. (2016). Catalysing the energy service market: the role of intermediaries. Energy Policy, 98, $420-430$.

Ofgem. (2016). Switching Programme Design Principles V1.0 DESIGN PRINCIPLES Impacts on customers. Retrieved from https://w0077w.ofgem.gov.uk/system/files/docs/2016 /06/switching_programme_design_principles.pdf

Okkonen, L., \& Suhonen, N. (2010). Business models of heat entrepreneurship in Finland. Energy Policy, 38(7), 34433452. https://doi.org/10.1016/j.enpol.2010.02.018.

Osterwalder, A. (2004). Business model ontology - PhD Thesis. l'Université de Lausanne.

Osterwalder, A., \& Pigneur, Y. (2010). Business model generation: a handbook for visionaries, game changers, and challengers. https://doi.org/10.1523/JNEUROSCI.0307-10.2010.

Osterwalder, A., Pigneur, Y., \& Tucci, C. L. (2005). Clarifying business models: origins, present, and future of the concept. Communications of the Association for Information Systems, 16(16), 1-25. http://aisel.aisnet.org/cais/vol16/iss1/1.

Owen, A., Mitchell, G., \& Gouldson, A. (2014). Unseen influence - the role of low carbon retrofit advisers and installers in the adoption and use of domestic energy technology. Energy Policy, 73, 169-179. https://doi.org/10.1016/j. enpol.2014.06.013.

Pätäri, S., \& Sinkkonen, K. (2014). Energy service companies and energy performance contracting: is there a need to renew the business model? Insights from a Delphi study. Journal of Cleaner Production, 66, 264-271. https://doi.org/10.1016/j. jclepro.2013.10.017.

Pettifor, H., Wilson, C., \& Chryssochoidis, G. (2015). The appeal of the green deal: empirical evidence for the influence of energy efficiency policy on renovating homeowners. Energy Policy, 79, 161-176. https://doi.org/10.1016/j. enpol.2015.01.015.

Richter, M. (2012). Utilities' business models for renewable energy: a review. Renewable and Sustainable Energy Reviews, 16(5), 2483-2493. https://doi.org/10.1016/j. rser.2012.01.072.

Roelich, K., Knoeri, C., Steinberger, J. K., Varga, L., Blythe, P. T., Butler, D., Gupta, R., Harrison, G. P., Martin, C., \& Purnell, P. (2015). Towards resource-efficient and service-oriented integrated infrastructure operation. Technological Forecasting and Social Change, 92, 40-52. https://doi. org/10.1016/j.techfore.2014.11.008.

Rosenow, J., \& Eyre, N. (2016). A post mortem of the Green Deal: austerity, energy efficiency, and failure in British energy policy. Energy Research and Social Science, 21, 141-144. https://doi.org/10.1016/j.erss.2016.07.005.

Seyfang, G., Park, J. J., \& Smith, A. (2013). A thousand flowers blooming? An examination of community energy in the UK. Energy Policy, 61, 977-989. https://doi.org/10.1016/j. enpol.2013.06.030.

Snape, J. R., Boait, P. J., \& Rylatt, R. M. (2015). Will domestic consumers take up the renewable heat incentive? An analysis of the barriers to heat pump adoption using agent-based modelling. Energy Policy, 85, 32-38. https://doi. org/10.1016/j.enpol.2015.05.008.

Sorrell, S. (2007). The economics of energy service contracts. Energy Policy, 35(1), 507-521. https://doi.org/10.1016/j. enpol.2005.12.009.

Sorrell, S., Schleich, J., O’Malley, E., \& Scott, S. (2004). The economics of energy efficiency: barriers to cost-effective investment. Books. Cheltenham: Edward Elgar.

Sovacool, B. K. (2015). Fuel poverty, affordability, and energy justice in England: policy insights from the Warm Front Program. Energy, 93, 361-371. https://doi.org/10.1016/j. energy.2015.09.016.

Steinberger, J. K., van Niel, J., \& Bourg, D. (2009). Profiting from negawatts: reducing absolute consumption and emissions through a performance-based energy economy. Energy Policy, 37(1), 361-370. https://doi.org/10.1016/j. enpol.2008.08.030.

Stieb, I., \& Dunkelberg, E. (2013). Objectives, barriers and occasions for energy efficient refurbishment by private homeowners. Journal of Cleaner Production, 48, 250-259. https://doi.org/10.1016/j.jclepro.2012.09.041.

Straub, A. (2016). Cohereno: COllaboration for Housing Nearly Zero-Energy RENOvation publishable report. Delft. Retrieved from http://www.cohereno. eu/fileadmin/media/Dateien/COHERENO-PublishableReport-2016.pdf

Sunikka-Blank, M., \& Galvin, R. (2016). Irrational homeowners? How aesthetics and heritage values influence thermal retrofit decisions in the United Kingdom. Energy Research \& Social Science, 11, 97-108. https://doi.org/10.1016/j. erss.2015.09.004.

Sweatman, P., \& Managan, K. (2010). Financing energy efficiency building retrofits international policy and business model review and regulatory alternatives for Spain. Climate Strategy and Partners. Madrid. Retrieved from www. climatestrategy.es

Teece, D. J. (2010). Business models, business strategy and innovation. Long Range Planning, 43(2-3), 172-194. https://doi. org/10.1016/J.LRP.2009.07.003.

The Rockefeller Foundation, \& DB Climate Change Advisors (2012). United States building energy efficiency retrofits market sizing and financing models.

Treib, O., Bähr, H., \& Falkner, G. (2007). Modes of governance: towards a conceptual clarification. Journal of European Public Policy, 14(1), 1-20. https://doi.org/10.1080 /135017606061071406. 
Upward, A., \& Jones, P. (2015). An ontology for strongly sustainable business models: defining an enterprise framework compatible with natural and social science. Organization \& Environment, 1-27. https://doi.org/10.1177 /1086026615592933.

Watson, A. (2014). To what extent has Green Deal policy facilitated energy efficiency retrofit supply chain development: a case study of Birmingham.

Webb, J., Hawkey, D., \& Tingey, M. (2016). Governing cities for sustainable energy: the UK case. Cities, 54, 28-35. https://doi.org/10.1016/j.cities.2015.10.014.

Willand, N. ., Ridley, I. ., \& Maller, C. . (2015). Towards explaining the health impacts of residential energy efficiency interventions - a realist review. Part 1: Pathways. Social Science and Medicine, 133, 191-201. https://doi. org/10.1016/j.socscimed.2015.02.005.
Wilson, C., Crane, L., \& Chryssochoidis, G. (2015). Why do homeowners renovate energy efficiently? Contrasting perspectives and implications for policy. Energy Research and Social Science, 7, 12-22. https://doi.org/10.1016/j. erss.2015.03.002.

Winther, T., \& Gurigard, K. (2017). Energy performance contracting (EPC): a suitable mechanism for achieving energy savings in housing cooperatives? Results from a Norwegian pilot project. Energy Efficiency, 10(3), 577-596. https://doi.org/10.1007/s12053-016-9477-0.

Zott, C., \& Amit, R. (2010). Business model design: an activity system perspective. Long Range Planning, 43(2-3), 216226. https://doi.org/10.1016/j.lrp.2009.07.004.

Zott, C., Amit, R., \& Massa, L. (2011). The business model: recent developments and future research. Journal of Management, 37(4), 1019-1042. https://doi.org/10.1177 $/ 0149206311406265$. 